\title{
Erratum zu: (Un)doing Gender empirisch
}

\section{Erratum zu:}

\section{J. C. Nentwich und F. Vogt (Hrsg.), (Un)doing Gender empirisch, https://doi.org/10.1007/978-3-658-32863-4}

Das Buch wurde versehentlich ohne Nennung des Förderers auf der Impressumseite veröffentlicht. Das Buch wurde nun entsprechend aktualisiert. 